\title{
Influence of Particulate Organic Carbon Sedimentation within the Seasonal Sea-ice Regime on the Catch Distribution of Northern Shrimp (Pandalus borealis)
}

\author{
René O. Ramseier ${ }^{1}$ and Caren Garrity \\ Microwave Group-Ottawa River, Inc. \\ 3954 Armitage Ave., RR\#1, Dunrobin, Ontario, Canada K0A 1 T0 \\ Don G. Parsons \\ Department of Fisheries and Oceans, Science Branch \\ P.O. Box 5667, St. John's, Newfoundland, Canada A1C 5X1 \\ and \\ Peter Koeller \\ Department of Fisheries and Oceans, Science Branch \\ P.O. Box 1006, Dartmouth, Nova Scotia, Canada B2Y 4A2
}

\begin{abstract}
A sedimentation model was used to map the distribution of particulate organic carbon (POC) in the Labrador Sea in relation to shrimp (Pandalus borealis) distribution. The model was based on information from sediment traps and ice regimes defined by: ice concentration, duration of ice cover and distance from an ice edge. Initial results from a subset of POC-binned commercial shrimp fishing data resulted in linear regression coefficients between catch per hour and POC of $r^{2}=0.926$ for 1989 and 0.964 for 1996. Binning the data according to depth resulted in $r^{2}=0.995$ and 0.948 , respectively. Shrimp catch data from research surveys binned by (1) POC, (2) depth and (3) temperature resulted in corresponding $r^{2}$ of (1) 0.304, (2) 0.763 , (3) 0.745 and (1) 0.535 , (2) 0.897 (3) 0.954 for 1996 and 1997, respectively. The results validate the sedimentation model and confirm the importance of POC as food for shrimp. Information on POC distribution determined by sedimentation models has potential applications in shrimp fisheries and research.
\end{abstract}

Keywords: Greenland Sea, Labrador Sea, particulate organic carbon, sea ice, sediment trap, shrimp catch

\section{Introduction}

The association between northern shrimp (Pandalus borealis) and fine sediments with a high organic content, which constitute a source of their food, is well known (Bigelow and Schroeder, 1939; Wigley, 1960; Haynes and Wigley (1969); Butler, 1971; Shumway et al., 1985; Koeller, 2000). For example, Haynes and Wigley (1969) reported that, in the Gulf of Maine, the occurrence of $P$. borealis was almost entirely restricted to areas of moderate ( 0.5 to $1.5 \%)$ to high $(>1.5 \%)$ amounts of organic carbon. The organic carbon food supply reaching the benthic community in any one area depends on the temporal and spatial patterns in the flux of primary production from the euphotic zone (Ritzrau et al., 2000). Ritzrau et al. (2000) used a POC model developed by Ramseier et al. (1999) to calculate a carbon budget for the East Greenland Sea which balanced POC production with the requirements of the benthic community, i.e. they established a pelagic-benthic coupling. The Newfoundland-Labrador Shelf is an important shrimp fishing area which has similarities to the Greenland Sea, including the presence of sea ice during winter-spring. These results suggested that an investigation into the relationship between the distribution of shrimp in the Newfoundland-Labrador Shelf obtained from survey and fishery data, and POC determined by a model incorporating information on

\footnotetext{
${ }^{1}$ Fellow, Hanse Institute for Advanced Study, Delmenhorst, Germany
} 
sea ice cover and sedimentation rates from sediment traps developed by Ramseier et al. (1999), could be potentially useful to the shrimp fishing industry and shrimp researchers wishing to obtain a more complete understanding of stock dynamics. This paper is the first to take this approach.

\section{Methods}

\section{Sediment Trap data}

Six automated Kiel Sonderforschungsbereich 313 (SFB) time series sediment traps (opening $0.5 \mathrm{~m}^{2}, 20$ collector cups; Salzgitter Electronics) were deployed at a depth of $500 \mathrm{~m}$ for the period 1988-96 (Ramseier et al., 1999). The traps were located in the Is OddenNordbukta region of the Greenland Sea, a dynamic sea ice area similar to the Labrador Shelf, although the formation of an ice tongue is unique to the former. The traps were moored below predominantly seasonal icecovered, cold, fresh surface water of polar origin. Consequently, the sedimentation model used in this paper incorporates features of hydrographic conditions in the Is Odden-Nordbukta region, and its application to the Labrador Sea will result in some differences in the extent and amount of POC sedimentation. However, we felt that for the purposes of this initial study, the differences between the model used and one incorporating conditions on the Labrador Shelf would be small, primarily because results are mainly influenced by the resolution of the satellite data $(25 \times$ $25 \mathrm{~km}$ ), which were available for the Labrador shelf.

Sediment trap sample analyses are described by Bodungen et al. (1991). Four of the traps were associated with currents that ranged from $3-6 \mathrm{~cm} \mathrm{~s}^{-1}$ at the surface to $2.45 \mathrm{~cm} \mathrm{~s}^{-1}$ at trap depth (Bourke et al. 1992). We assumed a sinking velocity of $100 \mathrm{~m} \mathrm{~d}^{-1}$ as proposed by Bauerfeind et al. (1994) for the rapidly settling fraction. This was based on a comparison of shallow and deep moored traps in the Greenland Sea and a mean easterly current speed of $3.5 \mathrm{~cm} \mathrm{~s}^{-1}$.

\section{Satellite Data}

Sea ice information was derived from the Special Sensor Microwave/Imager (SSM/I) of the United States Defense Meteorological Satellite Program which has been operational since 1987 (Hollinger et al., 1990). The data were provided by the National Snow and Ice Data Center, Boulder, Colorado (NSIDC, 1992). Brightness temperatures collected during the daily orbits were averaged onto an earth-located fixed grid of $25 \mathrm{~km} \times 25 \mathrm{~km}$. Ice concentrations were derived from these brightness temperatures using the NASA
Team algorithm (Cavalieri et al., 1984; Gloersen and Cavalieri, 1986).

The sinking velocities and current speeds used result in a settling area extending $15 \mathrm{~km}$ from a trap position. The satellite data grid size of $25 \mathrm{~km} \times 25 \mathrm{~km}$ per cell suggested that the model should resolve an area covering the trap position and one cell from that location. This covers a minimum particle-settling rate of $60.5 \mathrm{~m} \mathrm{~d}^{-1}$ for a distance of $25 \mathrm{~km}$. Two of the traps were associated with higher current velocities $(\approx 15 \mathrm{~cm}$ $\mathrm{s}^{-1}$, Fahrbach, Alfred Wegener Institute for Polar and Marine Research, pers. comm., 1994.) and were associated with three satellite grid cells to derive the mean sea ice concentration.

\section{Shrimp data}

Research survey data. Multispecies research surveys off Newfoundland and Labrador have been conducted annually since 1995 by the Department of Fisheries and Oceans, Canada, (DFO). These surveys employed a stratified-random sampling design and a lined, Campelen 1800 shrimp trawl as the sampling gear. The trawl was towed for 15 minutes at 3 knots at each survey station. Survey coverage has been extensive in areas off northeastern Newfoundland and southern Labrador $\left(49^{\circ} 15^{\prime} \mathrm{N}\right.$ to about $\left.54^{\circ} 45^{\prime} \mathrm{N}\right)$ where shrimp are abundant. Farther north, coverage has been less intensive and no surveys were conducted north of $61^{\circ} \mathrm{N}$. Analyses in this paper were restricted to areas south of $60^{\circ} \mathrm{N}$.

Data for surveys conducted in 1996 and 1997 include information on date, depth, bottom temperature, and standardized weight of shrimp caught per set. Research survey data was binned according to temperature $\left(0.4^{\circ} \mathrm{C}\right.$ bins, range -0.4 to 4.4$)$, depth (100m bins, range 100-1 500), and POC $\left(2 \mathrm{mg} \mathrm{m}^{-2} \mathrm{~d}^{-1}\right.$, range 10-32) for regression analysis.

Commercial fishery data. Data were selected for two years, including 1989 when ice cover was extensive, and 1996, a light ice year. During these years the Newfoundland-Labrador offshore shrimp fishing fleet consisted of about 12 large stern trawlers towing small-meshed otter trawls equipped with sorting grates to minimize by-catch. Details of fishing activity from $49^{\circ} 15^{\prime} \mathrm{N}$ to $60^{\circ} \mathrm{N}$ were obtained from official DFO logbook records. Information included date, location, depth, and catch, usually by individual fishing set. Logbooks accounted for most of the total effort each year and were considered representative of the fishing activity of the fleet. 
For commercial fishery data, depth data were binned in $50 \mathrm{~m}$ intervals from $150-800 \mathrm{~m}$ and POC data were binned as per the research vessel data.

\section{Particulate Organic Carbon Model}

The original model developed by Ramseier et al. (1999) using information from 5 sediment traps, quantifies POC sedimentation and provides an annual sedimentation pattern. We applied the model to the Labrador Sea by using the mean annual sea ice concentration in the area obtained from the passive microwave satellite data. The model was also upgraded to include information from a sixth trap.

The model components include the mean annual sea ice regime $\left(I R_{\% y}\right)$ defined as

$$
I R_{\% y}=\Sigma c / 365
$$

where $c$ represents the daily ice concentration in percent summed over an entire year (Ramseier et al., 1999). The second component represents the annual POC values for the respective traps (Ramseier et al., 1999). The mean annual ice concentration as shown in Fig. 1 displays the great variability in ice concentrations associated with the trap positions. The POC curves represent the measured values $\left(\mathrm{POC}_{\text {meas }}\right)$ as well as the calculated values using (2) below. Applying a linear regression to $\mathrm{POC}_{\text {meas }}$ and ice concentration data results in an equation for calculating the amount of POC sedimentation in $\mathrm{g} \mathrm{m}^{-2} \mathrm{y}^{-1}$

$$
P O C=0.0743 * I R_{\% y}+1.4343 \quad r^{2}=0.861
$$

Note that (2) provides an annual, average POC sedimentation rate at the $500 \mathrm{~m}$ depth which can be applied to the Is Odden-Nordbukta region of the Greenland Sea. Furthermore (2) is only valid for the mean annual concentration range between $18 \%$ and $64 \%$. The reader is referred to Ramseier et al. (1999) for further details. It suffices to say that the ice concentration range is based on the time span of all the active periods of individual trap cups. The model results are included in Fig. 1, and provide a direct comparison with the measured values. The use of all six traps provided a marginal improvement in the regression coefficient $\left(r^{2}\right)$ from the original value of 0.852 to 0.861 .

The sediment pattern for POC is given by the empirical equation in $\mathrm{mg} \mathrm{m}^{-2} \mathrm{~d}^{-1}$ based on individual cup openings of all six-sediment traps. It represents a maximum value and is best used as a relative amount if applied to areas other than the Is Odden-Nordbukta region.

$$
P O C=a+b \sqrt{\frac{c \times d}{\pi I R \% y^{3}}} e^{-c\left(\ln \frac{I R \% y}{d}\right)^{2}}-\frac{1}{16 c}+(-\operatorname{ltIR} \% y)
$$

$a, b, c, d$ and $l t$ are the constants corresponding to 7.19 , 1400, 1.3, 50, and -0.0645 (Ramseier et al. 1999). The ice regime $I R_{\% y}$ is defined in (1).

The model can best be described schematically (Fig. 2). The seasonal sea ice cover is usually referred to as the Marginal Ice Zone (MIZ) which extends from the ice limit to the coast. Based on sediment trap results, the slice of ocean depicted in the diagram can be divided into five subareas representing distinct biological zones (Ramseier et al., 1999). The first subarea (1) is ice-free, extending from the open ocean to a point $80 \mathrm{~km}$ from the mean maximum ice limit, and represents the open ocean sedimentation component of total sedimentation flux. We used a value of $1 \mathrm{~g} \mathrm{~m}^{-2} \mathrm{y}^{-1}$ for subarea (1) based on results from a trap located in the Is Odden-Nordbukta region (Noji et al., 1999). The second subarea (2) is a primary production belt 80 $\mathrm{km}$ wide, parallel to the mean maximum ice limit, as observed by Smith et al. (1987). A POC flux of $2.62 \mathrm{~g}$ $\mathrm{m}^{-2} \mathrm{y}^{-1}$ obtained from all traps was used (Ramseier et al., 1999). The third subarea (3) is seasonal and is located between the mean maximum ice limit $(0 \%)$ and the $18 \%$ ice concentration boundary. The flux value used was the same as for subarea (2). Subarea (4) is the most biologically active zone and spans the area between ice concentrations of $18-64 \%$. Its average POC sedimentation rate is given by equation (2), and its distribution by equation (3). This is the area of interest for the analysis in this paper. Subareas (2) to (4) are identified as the Biological Marginal Ice Zone (BMIZ) because they are biologically productive. The last subarea (5) is a quasi-permanent part of the ice cover that extents from the $64 \%$ ice concentration contour to the coast and was assigned a POC flux of $1.83 \mathrm{~g} \mathrm{~m}^{-2} \mathrm{y}^{-1}$ (Ramseier et al., 1999).

The model was developed for a sedimentation depth of $500 \mathrm{~m}$. When POC sedimentation was recalculated using the exponential equation from Martin et al. (1987) for the depths at which most shrimp were caught $(200-400 \mathrm{~m})$ on the Labrador Shelf the differences were small, consequently the effect on model results is also expected to be minimal. 


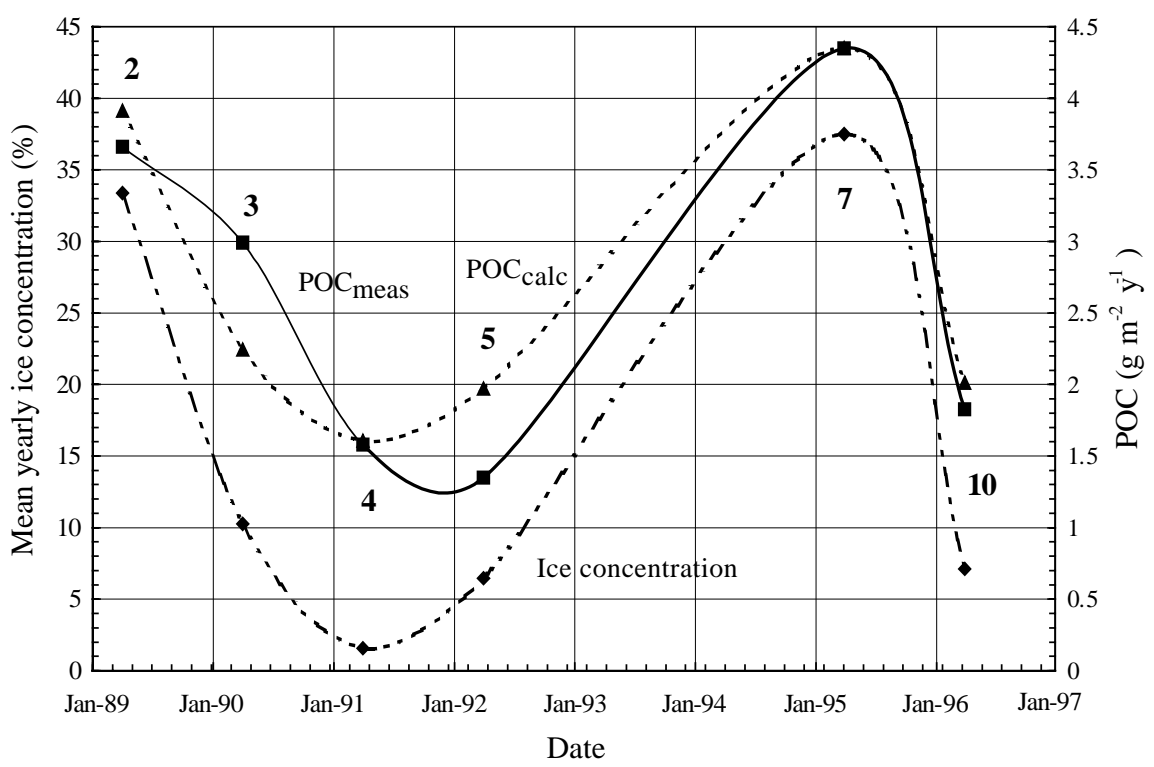

Fig. 1. Results from the Greenland Sea analysis depicting the parameters $\left(I R_{\%}\right)$, the mean yearly ice concentration and particulate organic carbon ( $\mathrm{POC}_{\text {meas }}$ ) contained in each sediment trap (identified by number). The model results $\left(\mathrm{POC}_{\text {calc }}\right)$ are based on equation (2). The coefficient of determination based on a linear regression between $\left(I R_{\% y}\right)$ and $\left(\mathrm{POC}_{\text {meas }}\right)$ is 0.861 .

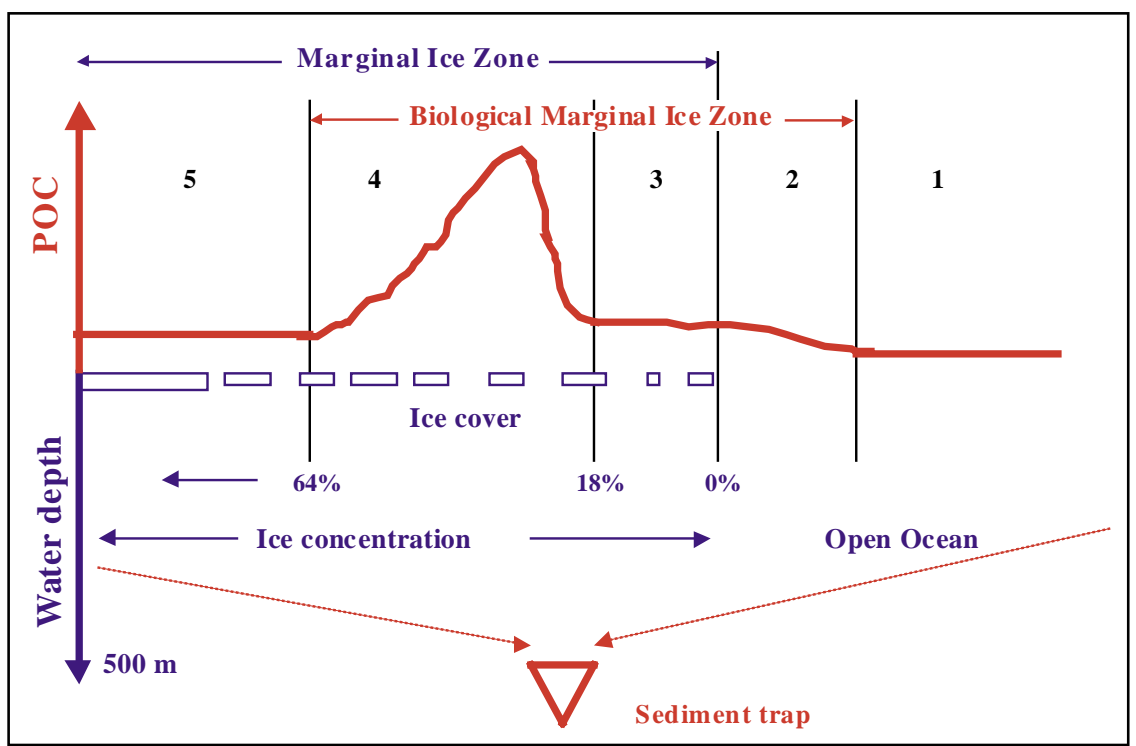

Fig. 2. Schematic model for the POC sedimentation across slice of ocean from the coast (left) to the open ocean (right). The numbers identify the subareas discussed in the text, representing different sedimentation processes. 


\section{Results}

Figure 3 gives fishing positions and the mean annual ice concentration for 1989, 1996 and 1997. The southern ice boundary extended the furthest south in 1997 (to $\left.47^{\circ} \mathrm{N}\right)$, followed by $1989\left(47^{\circ} 30^{\prime} \mathrm{N}\right)$ and 1996 $\left(50^{\circ} \mathrm{N}\right)$. The total area covered by ice, i.e from the southern ice limit to $60^{\circ} \mathrm{N}$, was greatest for 1997 (362 $503 \mathrm{~km}^{2}$, with a mean annual ice concentration of $16.2 \pm 10.7 \%)$, followed by $1989\left(361990 \mathrm{~km}^{2}\right.$, $16.7 \pm 10.7 \%)$ and $1996\left(332596 \mathrm{~km}^{2}, 15.8 \pm 13.5 \%\right)$. Applying equation (3) to the Labrador Sea ice regime for these years resulted in the POC distribution shown in Fig. 4. The extent and southern limit of the POC distribution mimic the ice regime i.e. 1997>1989>1996. Note that the POC distribution shown is for the most biologically active subarea 4 , i.e. the $18 \%$ to $64 \%$ ice concentration range. The highest intensity of POC (about $32 \mathrm{mg} \mathrm{m}^{-2} \mathrm{~d}^{-1}$ ) was associated with a maximum of $30 \%$ ice concentration (Ramseier et al., 1999).

The relationship between $\mathrm{POC}$, commercial fishery and research vessel shrimp catches and the binned temperature, depth and POC data are given in Fig. 5-6. Linear regression coefficients between shrimp catch and POC are given within each figure and in Table 1 .

For research vessel data, the pattern of change across the temperature bins was similar for both POC and shrimp catch for both years (Fig. 5, top). Each year showed three peaks at similar temperatures, however, the 1997 data showed the best correlation between shrimp and POC. Similarly, the pattern across depth bins (Fig. 5, middle) showed one peak between 200-400 $\mathrm{m}$ for both POC and shrimp catch in both years, the 1997 data giving the best correlation. There was no correlation between POC and shrimp for the POC binned data (Fig. 5, bottom) in 1996, but the 1997 data showed some correspondence.

Commercial fishery data exhibited the best correlation between POC and shrimp catch (Fig. 6) with relatively high correlation coefficients for both years examined. This was true for both the POC and depth binned data. It is noteworthy that, with the exception of the research vessel data in 1996, both research survey and commercial data showed the highest shrimp catches in relatively high or in the highest POC bins i.e. $>30 \mathrm{mg}^{-2} \mathrm{~d}^{-1}$ for the 1997 survey and 1989 commercial data, and near $30 \mathrm{mg}^{-2} \mathrm{~d}^{-1}$ for the 1996 commercial data (Fig. 5 and 6).

\section{Discussion}

The association between shrimp and POC is clearly evident in Fig. 5 and 6 and Table 1, despite differences in the strength of this association between commercial fishery and research vessel data. The stronger association (higher $r^{2}$ ) in the commercial shrimp catches must be at least partly due to differences in the distribution of fishing positions (Fig. 4). Fishing locations for the multispecies research surveys are determined by stratified-random sampling, which spreads effort throughout the sampling area, encompassing areas of both high and low shrimp abundance. Commercial shrimp catches are restricted to a few patches where experience has consistently found high shrimp concentrations. The commercial data were located within the mean annual sea-ice extent. Furthermore, most of the commercial fishing positions were located within the elevated POC sedimentation area (Fig. 4). Also, the relatively large amount of fishing positions for commercial $(\mathrm{N}=7807$ for 1989 , 4369 for 1996) compared to the survey data $(\mathrm{N}=397$ for 1996, 402 for 1997) would have contributed to the better correlations in the commercial data.

Both depth and POC binned commercial data showed a strong association $\left(r^{2}>0.9\right)$ between shrimp catch and POC for the two years examined (Fig. 6). Preferred fishing depths changed little between years ( $375 \pm 25 \mathrm{~m}$ in 1989 and $425 \pm 25 \mathrm{~m}$ in 1996) and both depth peaks are well within the BMIZ subarea (4). However, the pattern of the POC binned data differed between years. In 1989 most shrimp were caught in areas with POC levels $>25 \mathrm{mg} \mathrm{m}^{-2} \mathrm{~d}^{-1}$ while in 1996 maximum catches were at much lower levels (15 and $\left.25 \mathrm{mg} \mathrm{m}^{-2} \mathrm{~d}^{-1}\right)$. The percentage of the total shrimp catch at POC levels $>15 \mathrm{mg} \mathrm{m}^{-2} \mathrm{~d}^{-1}$ was $97 \%$ in 1989 and $77 \%$ in 1996 . The reason for this differences is unclear and will require additional data and analysis.

For research vessels the percentage of the total shrimp catch at POC levels $>15 \mathrm{mg} \mathrm{m}^{-2} \mathrm{~d}^{-1}$ was $57 \%$ for 1996 and $80 \%$ in 1997 . The lower percentage of the total catch taken in the higher POC areas by research vessel in 1996 compared to commercial catches in the same year may be due to differences in the sampling method as described above. This may also acount for the slightly shallower peak catches in survey compared to commercial data. The reason for the considerable difference in the temperatures $\left(\sim 1^{\circ} \mathrm{C}\right)$ where shrimp concentrated between the two survey years is unclear, however, both peaks fall well within the preferred temperature range of the species. 

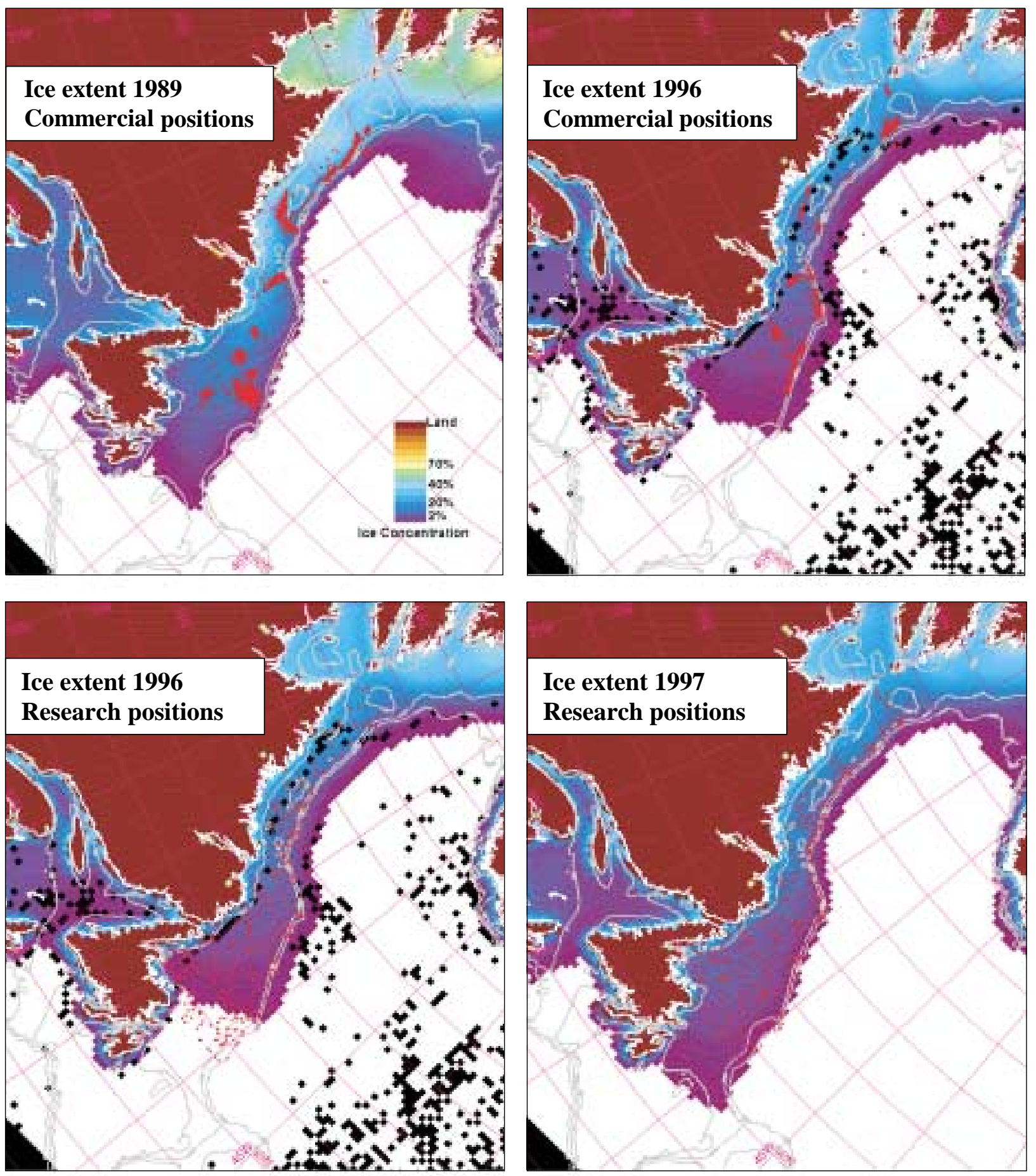

Fig. 3. Mean annual sea ice extent along the Newfoundland and Labrador Coasts for the three years examined. Red dots indicate fishing positions for both the commercial shrimp fishery and research vessel surveys. The bathymetry contours are for depths of 150,600 and $1200 \mathrm{~m}$. The black points, predominantly in the open ocean are satellite dropouts (no data). 

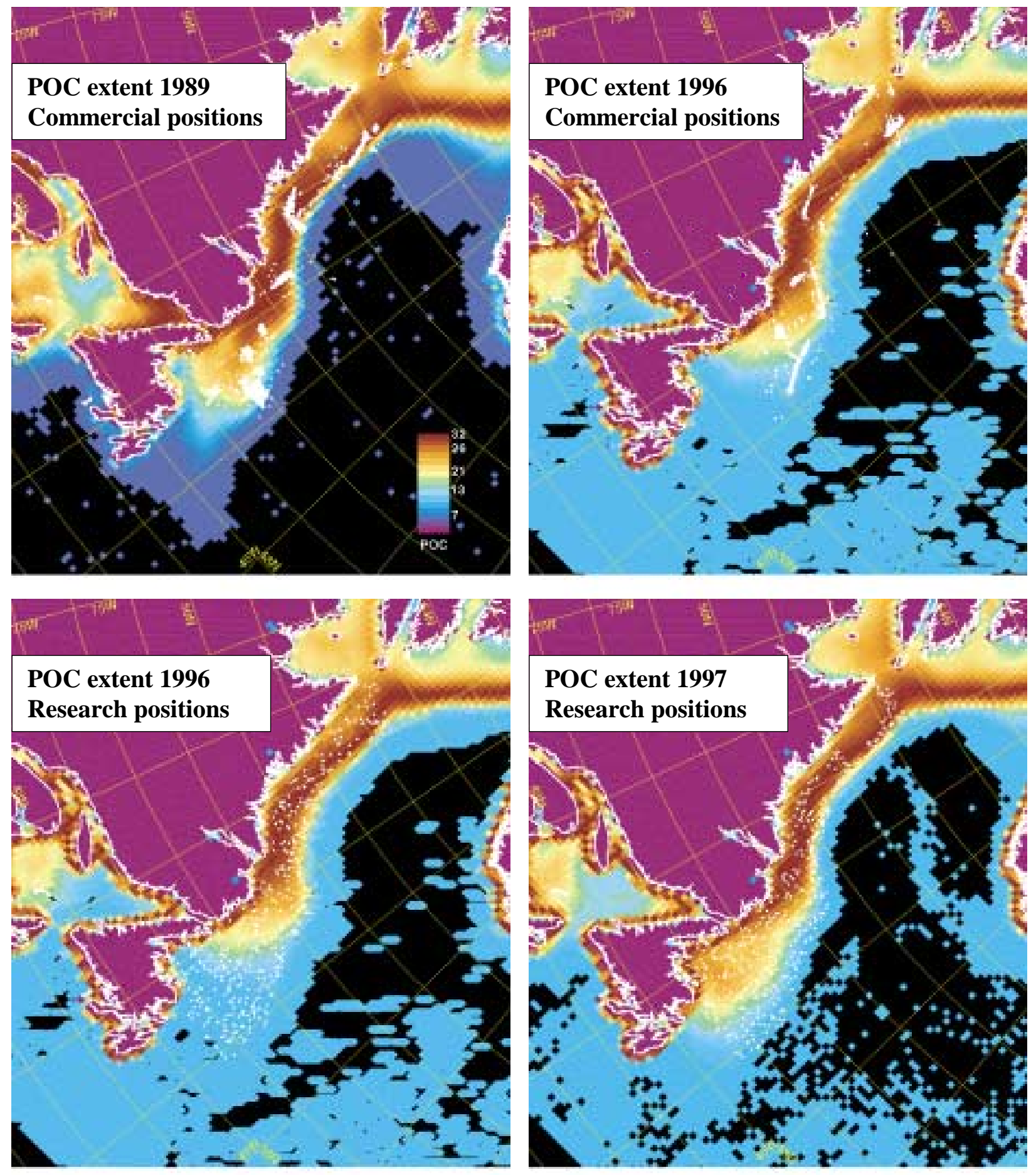

Fig. 4. Mean annual POC distribution $\left(\mathrm{mg} \mathrm{m}^{-2} \mathrm{~d}^{-1}\right)$ for subarea 4. The POC distribution is obtained by applying equation 3 to the mean ice concentration shown in Fig. 4. Shown also are the commercial shrimp and research vessel survey fishing positions. 

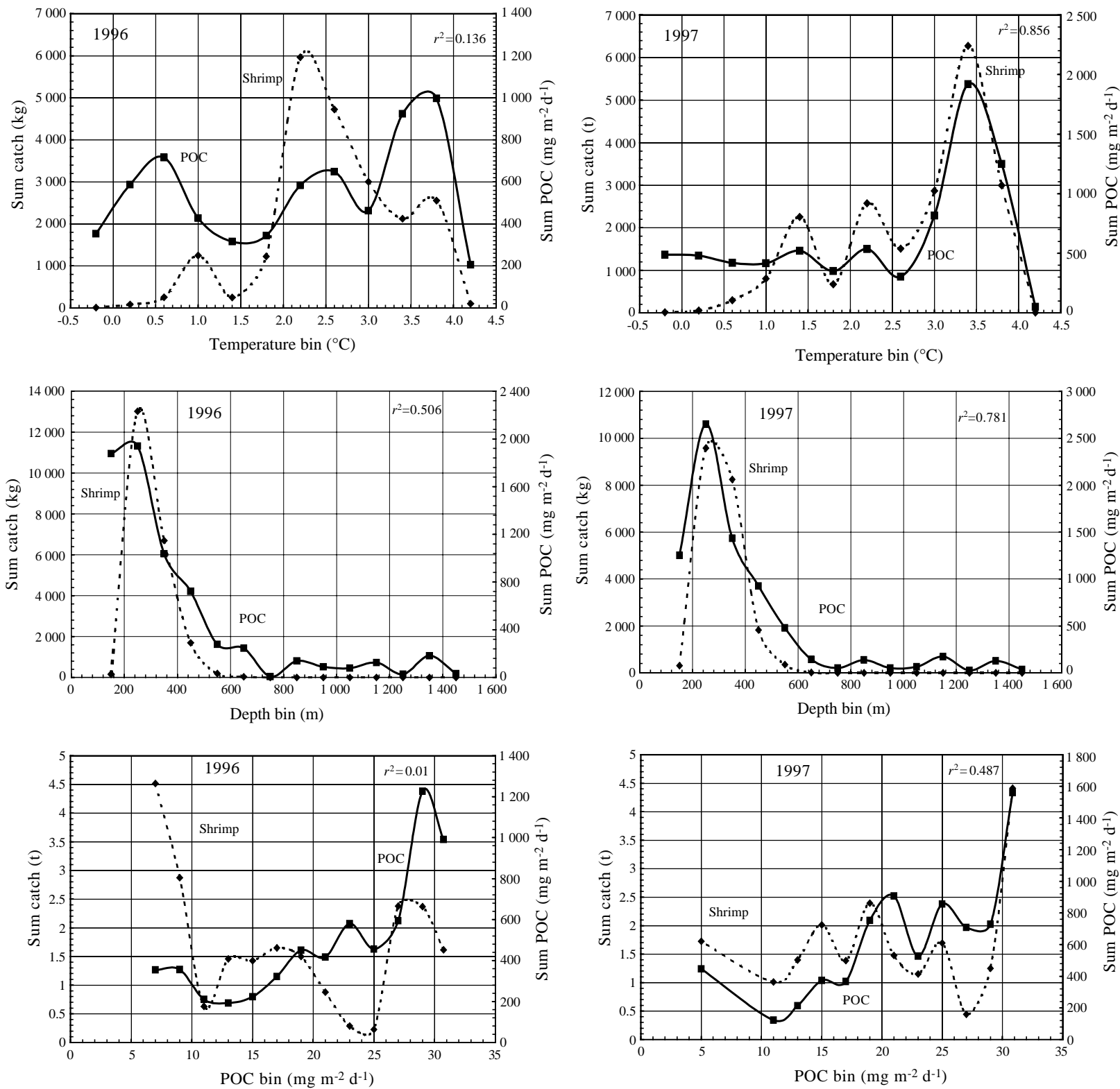

Fig. 5. Research vessel data, showing total shrimp catch per standard set and POC, summed within temperature (top), depth (middle) and POC (bottom) bins. The linear regression coefficient $r^{2}$ is shown.

As previously noted, differences in the current conditions between the Labrador coast and the area on which the model is based will result in some differences in POC distribution. In addition, there may be differences in actual sedimentation rates between areas due to differences in primary production. However, initial results are encouraging and suggest that an upgrade to the model should be pursued for areas where a better understanding of the relationship between shrimp abundance and environmental variables is desirable. Upgraded model results may also be usefull in determining the location of potential shrimp fishing grounds.

\section{Acknowledgements}

We thank the SeaSpace Corporation, Poway, California for the use of their TeraScan software. One of the authors (ROR) would like to thank Renato Landert for stimulating discussions about his fishing 

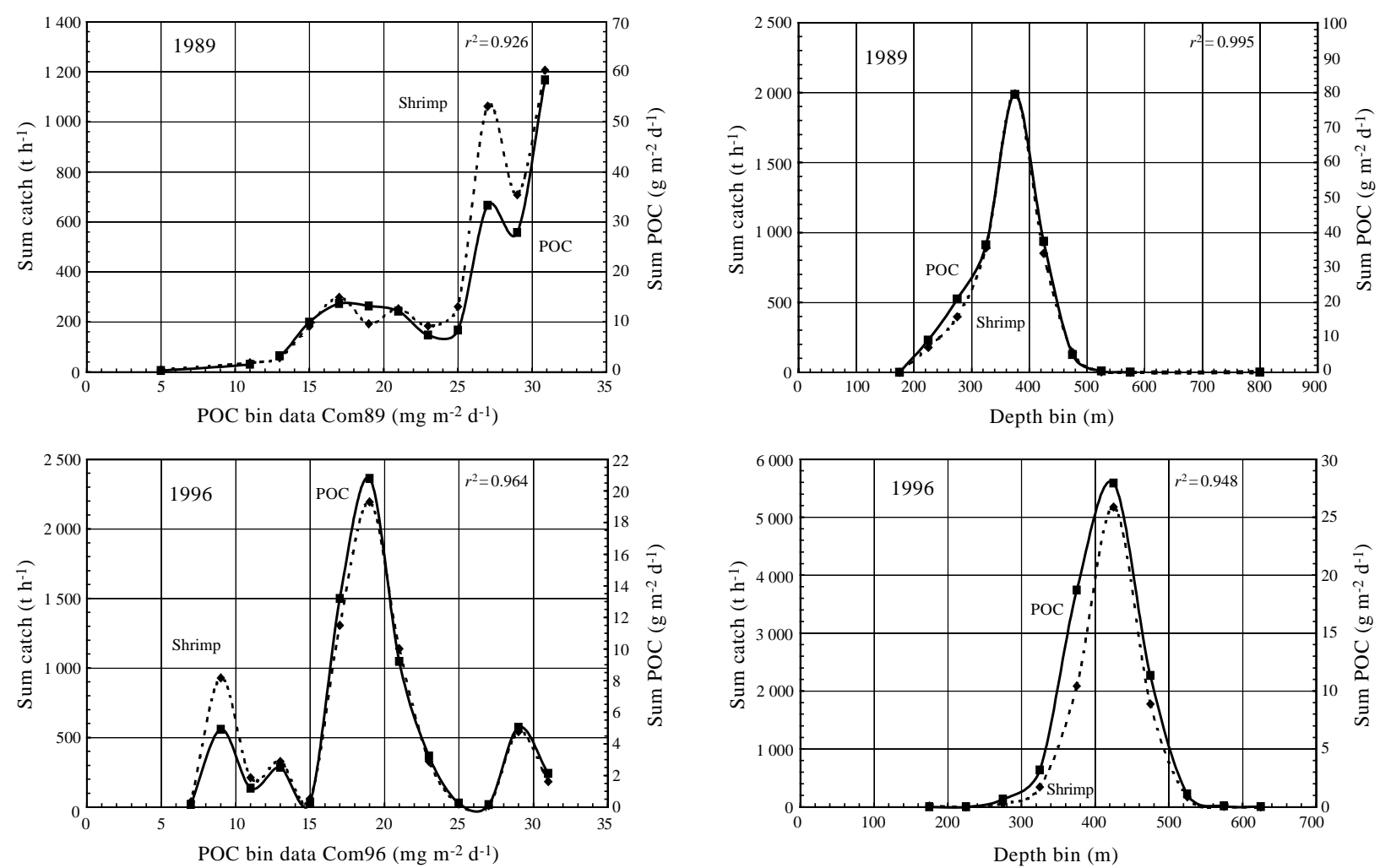

Fig. 6. Commercial fishery data, showing total shrimp catch per hour and POC, summed within POC (left) and depth (right) bins. The linear regression coefficient $r^{2}$ is shown.

TABLE 1. Regressions coefficients for the commercial (Com) and research vessel (Res) shrimp data versus POC for the temperature, depth and POC binned data shown in Figs. 5-6.

\begin{tabular}{lcccc}
\hline \hline Year & Com 1989 & Com 1996 & Res 1996 & Res 1997 \\
\hline Parameter & Catch & Catch & Catch/tow per hr & Catch/tow per hr \\
Temperature & No data & No data & 0.136 & 0.856 \\
Depth & 0.995 & 0.948 & 0.506 & 0.781 \\
POC & 0.926 & 0.964 & 0.01 & 0.487 \\
\hline
\end{tabular}

experiences onboard the fishing trawler "Ocean Prawns". We also thank Manfred Stein and an anonymous reviewer for the critical comments, which improved and clarified the content of this paper significantly.

\section{References}

BAUERFEIND, E., B. V. BODUNGEN, K. ARNDT, and W. KOEVE. 1994. Particle flux and composition of sedimenting matter, in the Greenland Sea. J. Mar. Sys., 5: 411-423.

BIGELOW, H. R., and W. C. SCHROEDER. 1939. Notes on the fauna above the mud bottoms in deep water in the Gulf of Maine. Biol. Bull. (Woods Hole) 76: 305324.

BODUNGEN, V. B., M. WUNSCH, and H. FÜRDERER. 1991. Sampling and analysis of suspended particles, in the North Atlantic. In: Marine particles: Analysis and characterization. D.C. Hurt and D.W. Spencer (eds.), Geophys. Res., 97: 7241-7250.

BOURKE, H. R., R. G. PAQUETTE, and R. F. BLYTHE. 1992. The Jan Mayen current of the Greenland Sea.J.Geophysical Monograph Series, American Geophysical Union, Washington DC, 63: 47-53.

BUTLER, T. H. 1971. A review of the biology of the pink shrimp, Pandalus borealis Krøyer 1838. Can. Fish. 
Rep., 17:17-24.

CAVALIERI, D. J., P. GLOERSEN, and W. J. CAMPBELL. 1984. Determination of sea ice parameters with the NIMBUS-7 SMMR. J. Geophys. Res., 89: 5355-5369.

GLOERSEN, P., and D. J. CAVALIERI. 1986. Reduction of weather effects in the calculation of sea ice concentrations from microwave radiances. J. Geophys. Res., 91: 3913-3919.

HAYNES, E.B., and R.L. WIGLEY, 1969. Biology of the northern shrimp, Pandalus borealis, in the Gulf of Maine. Trans. Amer. Fish Soc., 98:60-76.

HOLLINGER, J., J. PIERCE, and G. POE. 1990. SSM/I instrument evaluation, IEEE Trans. Geosci. Remote Sensing, 28: 781-790.

KOELLER, P. A. 2000. Relative importance of abiotic and biotic factors to the management of the Northern Shrimp (Pandalus borealis) fishery on the Scotian Shelf. J. Northw. Atl. Fish. Sci., 27: 21-33.

MARTIN, J. H., G. A. KNAUER, D. M. CARL, and W. W. BROENKOW. 1987. VERTEX: Carbon cycling in the Northeast Pacific. Deep-Sea Res., 32: 267-285.

NOJI, T. T., F. REY, L. A. MILLER, K. Y. BØRSHEIM, and J. URBAN-RICH. 1999. Fate of biogenic carbon from surface waters in the central Greenland Sea. Deep Sea Res. II, 46: 1497-1509 NSIDC.

1992. DMSP SSM/I brightness temperature and sea ice concentration grids for the Polar Regions on CD-ROM user's guide, National Snow and Ice Data Center, 1, Boulder, Colorado.

RAMSEIER, R. O., C. GARRITY, E. BAUERFEIND, and R. PEINERT. 1999. Sea-ice impact on long term particle flux in the Greenland Sea's Is Odden-Nordbukta region, 1985-1996. J. Geophys. Res. 104: 5329-5343.

RITZRAU, W., G. GRAF, A. SCHELTZ, and W. QUEISSER. (2000, in press). Bentho-pelagic coupling and carbon dynamics in the northern North Atlantic. In: The northern North Atlantic: a changing environment, P. Schäfer, W. Ritzrau, M. Schlüter, and J. Thiede (eds.), Springer Verlag,

SHUMWAY, S., H. C. PERKINS, D. F. SCHICK, and A. P. STICKNEY. 1985. Synopsis of biological data on the Pink Shrimp, Pandalus borealis Krøyer, 1938. NOAA Technical Report NMFS 30, FAO Fisheries Synopsis No. 144.

SMITH, W.O., M.E. BAUMANN, D.L. WILSON, and L. ALETSEE, 1987. Pyotoplankton biomass and productivity in the marginal ice zone of the Fram Strait during the summer 1984. J. Geophys. Res., 92: 67776786.

WIGELY, R.L. 1960. Note on the distribution of Pandalidae (Crustacea, Decapoda) in New England waters. Ecology, 41: 564-570. 